No. 30, December 1965

\title{
質量分析による分子構造の推定法 低エネルギー電子衝撃について
}

\author{
Study on The Structure Determination of Organic Compounds by Mass \\ Spectrometry; Low Energy Electron Bombardment
}

\author{
土屋正 彦*，松比良伸 也*，石 堂 怜*
}

Masahiko Tsuchiya, Shinya Matsuhira and Satoshi Ishido

(1965年 8 月29日受理)

\begin{abstract}
Mass spectrum is closely related with the structure of a compound. But it is not easy to determine the structure from its mass spectrum, because the behavior of molecule under electron bombardment is rather complicated and in many cases there are several compounds which show the similar mass spectrum. It can be said that when the energy of the bombarding electrons changed, the dissociation process of a given molecule may be also change. We investigated the correlations between the structure of a compound and its mass spectrum at various energy bombardments, by using a CEC 21-103C mass spectrometer. The optimum operating condition and the reproducibility of mass spectrum at low energy bombardment are also described in this report. It was found that mass spectrum at low energy bombardment was tolerably reproducible and was closely related with the structure of the compound.

The formation of the large majority of ions under low energy (2-4 eV higher than its ionization potential) bombardment is through the simple cleavage of a weak bond and the rearrangement. In some cases the rearrangement of parent ion gives the largest peak, such as the peak at $\mathrm{m} / \mathrm{e} 33$ in the spectrum of iso-butyl alcohol, at low energy bombardment.

It is believed that very useful informations for correct interpretation of mass spectrum can be obtained by comparing the spectrum at low energy boambardment with that at ordinery measurement and the ionization efficiency curves are also useful.
\end{abstract}

\section{1. 緒言}

質量スペクトルは化合物の構造と密接な関係がある ので，赤外吸収スペクトルなどとともに有機化合物の 構造解析に利用されており, 最近は高分解能の装置も 開発され，質量分析は有力な機器分析法の一つになっ ている。

しかし質量スペクトルはかなり複雑で, 分子内転位 によるイオンなごが生成するために，スペクトルから 分子構造を推定するのは必ずしあ簡単ではない。八口 ゲンを会む化合物のようにフラグメントイオンの質量 数が特異な場合は解析し易いが, 炭化水素や酸素, 窒 素を含む化合物は，同じ質量数で構造の異なるフラグ メントを生ずるととが多く, 反応生成物の構造推定な ど，汃なり困難な場合も多い。

スペクトルから構造を推定しようという試みは今ま でにもあり ${ }^{1 / 21}$ ，スペクトル data 集3)4) などああるが， これだけではとても十分とはいえない。

試料をイオン化するのに通常電子衝撃法が用いられ

東京大学工学部 (東京都文京区本楖)

University of Tokyo (Hongo, Bunkyo-ku. Tokyo)
るが，乙の電子のエネルギーが大きいために（70〜 $90 \mathrm{eV})$ 種々の結合の切れた多種類のフラグメントイオ ンができ，乙のとともスペクトルが複雑で解析がしに くい原因になっていると思われる。イオン化を行なう 電子のエネルギーを変えれば, フラグメントイオンの でき方も変る筈であり, この変化の仕方と分子構造の 関係を調べれば，通常のように電子のエネルギーが $70 \mathrm{eV}$ のときの質量スペクトルだけから解析するより あ得られる知見が多くなり, 構造推定が容易になると 考えられる。

この関係を調べるために二，三の含酸素脂肪族化合 物について測定を行ない, 良好な結果を得た。一部は 分析化学誌に報告した ${ }^{5)}$ が，てこに主として低エネル ギー電子衝撃法についてまとめて報告する。

\section{2. 装 置}

装置は CEC 21-103 C 型質量分析計を用い, 回路 の一部を Fig. 1 に示すように改造して電子加速電圧 を 3〜100V の笘国で変えられるようにした。改造し た部分は破線で示したが， $100 \mathrm{k} \Omega$ のヘリポット， 2 $\mathrm{k} \Omega$ の固定抵抗，および 6 接点のスイッチ 1 個 (Fig. 


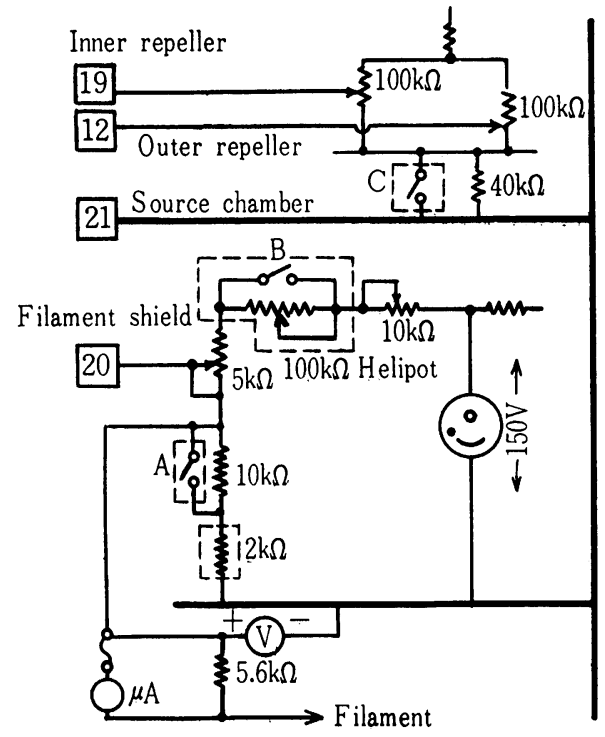

Fig. 1. Modification of the isatron control circuit of CEC21-103C mass spectrometer for low voltage operation.

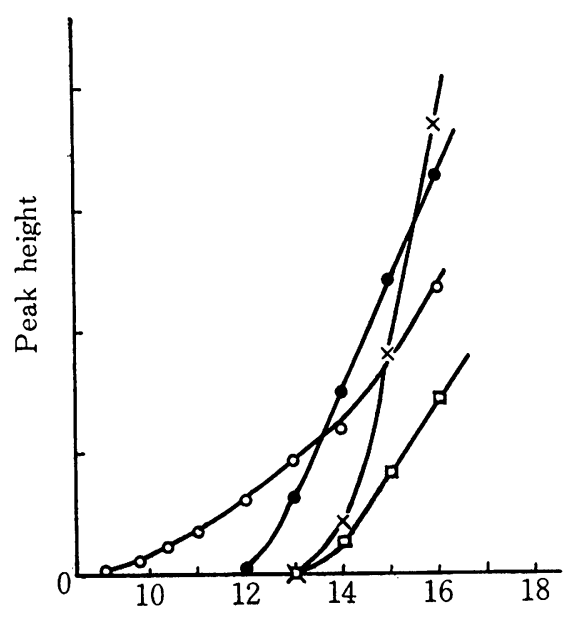

Electron accelerating vol tage, $\mathrm{V}$

Fig. 2. Ionization efficiency curves of argon, carbon dioxide, $n$-butane, and nitrogen.

$$
\begin{array}{ll}
-\times- & \mathrm{Ar}(\mathrm{I} . P .=15.77 \mathrm{eV}) \\
- & \mathrm{CO}_{2}(\mathrm{I} . \mathrm{P} .=13.85 \mathrm{eV}) \\
- & n-\mathrm{C}_{4} \mathrm{H}_{10}(\mathrm{I} . P .=10.4 \sim 10.8 \mathrm{eV}) \\
-\square- & \mathrm{N}_{2}(\mathrm{I} . \mathrm{P} .=15.60 \mathrm{eV})
\end{array}
$$

\begin{tabular}{|c|c|c|c|c|c|}
\hline \multirow{2}{*}{ switch position } & \multirow{2}{*}{$\begin{array}{l}\text { Range of electron } \\
\text { accelerating voltage } \\
\text { (V) }\end{array}$} & \multirow{2}{*}{$\begin{array}{l}\text { Repeller voltage } \\
\text { minimum } \\
\text { (V) }\end{array}$} & \multicolumn{3}{|c|}{ Switch function* } \\
\hline & & & $\overparen{A}$ & B & C \\
\hline $\mathrm{L}$ & $3 \sim 18$ & 0 & 0 & $x$ & 0 \\
\hline M & $18 \sim 40$ & & 0 & 0 & 0 \\
\hline $\mathrm{H}$ & $65 \sim 100$ & about $1 \%$ of ion & $x$ & 0 & $x$ \\
\hline $\mathrm{X}$ & $14 \sim 100$ & accelerating voltage & $x$ & $x$ & $x$ \\
\hline
\end{tabular}

Table 1 Ranges of electron accelerating voltage at four switch positions

* $\mathrm{A}, \mathrm{B}, \mathrm{C}=\mathrm{a}$ part of the switch, shown in Fig. 1. $\bigcirc$ : Switch on, $\times:$ Switch off

1 の A， B，C で示した部分) をつけた部分である。 $2 \mathrm{k} \Omega$ の固定抵抗は図には示さなかったが $1800 \Omega$ と $200 \Omega$ の抵抗を直列につないだあので $200 \Omega$ の闰端は ポテンショメータに接続できるようにしてあり， $11 \mathrm{~V}$ 以下の電子加速電王は正確に測るととができる。この スイッチの切り替えにより Table 1 亿示したように 電子加速電玨は 4 種の籍围内で変えられ，スイッチの 位置 L と $\mathrm{M}$ では $(3 \sim 40 \mathrm{~V})$, リペラー電㕩は 0 に できる。てのリペラー電圧の影帮については後に述べ る。

\section{3. 測定条件の検討}

\section{1. 電子のエネルギー幅について}

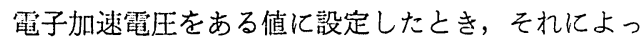
て電子が得るエネルギーはある幅を持っている。我々 の用いているような日常分析用の装置では, ての幅が 広いのでイオン化電生や出現電理を测定するには適当
でない。しかし少し位幅があってあ，分子内のある結 合が切れるためには，1 数 $\mathrm{eV}$ のエネルギーが必装 であるから，電子加速電正によりスペクトルにも差が

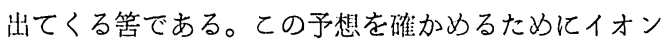
化電生のよく知ら机ているアルゴンなどについてイオ ン化刘率曲線を測定した。乙の結果を Fig. 2, 3, 5 7 に示した。エネルギー幅は $\pm 1 \sim 2 \mathrm{~V}$ で，イオン化電 王付近まで下げると親イオンだけにはならないが，フ ラグメントの少ない，構造と閉連のあるスペクトルが 得られるととがわかった。

\section{2. リペラー電圧の影響}

電子加速電珢を低くした場合，リペラー電压が高い と, 乙の電圧により電子が加速を受けるために結局択 山のフラグメントができることになり，また低すぎて あ生成したイオンを十分に追し出すととができないて とになる。リペラー電圧の影響を調べた結果の一部を

Table 2 に示す。 


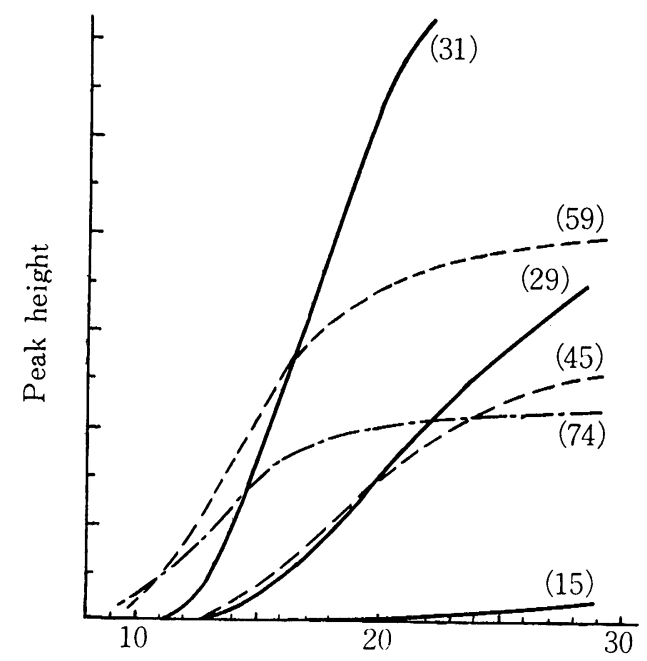

Electron accelerating voltage, $\mathrm{V}$

Fig. 3. Ionization efficiency curves of diethyl ether.
Table 2 でわかるように Outer Repeller のダイヤ ルを10にした場合 (Table 2 の右端) に，フラグメン トが少ない簡単なスペクトルが得られてしかも感度が 一番良かった。乙れが 3.3., 3.4. でも述べるうに最 適のリペラー電圧で, 本実験はすべてての条件(Outer Repeller 10目盛, Inner Repeller 20 目盛，スイッチ C は閉じる)で行なった。

またスイッチ C が開いて $40 \mathrm{k} \Omega$ の抵抗に生ずる電 正がリペラーに加わる場合には，電子加速電死を低く

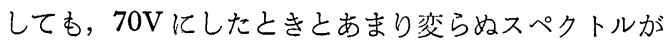
得られ，リペラ一電王の影蠁が大きいととがわかった。 (Table 2 有加ら 2 列目)

\section{3. イオン化電流 (電子電流) の影響}

電子加速電仼を低くすると，生成するイオンの量が 少なくなり，本装置の検出器の感度はあまり良くない ので, パタン係数の小さいイオンは検知しにくくなる。 從ってフラグメントの少ない簡単なスペクトルが得ら れて，しかむできるだけピークの高さが高くなるよう な条件で測定することが望ましい。

Table 2 Peak heights and pattern coefficients of $n$-butane at various operating conditions

\begin{tabular}{|c|c|c|c|c|c|c|c|c|}
\hline $\begin{array}{l}\text { Electron } \\
\text { accelerating voltage } \\
\text { (V) }\end{array}$ & \multicolumn{2}{|c|}{11.00} & \multicolumn{2}{|c|}{13.0} & \multicolumn{2}{|c|}{11.1} & \multicolumn{2}{|c|}{11.00} \\
\hline $\begin{array}{l}\text { Repeller } \\
\text { voltage } \\
\text { dial }\end{array}\left\{\begin{array}{l}\text { I.R. } \\
\text { O.R. }\end{array}\right.$ & \multicolumn{2}{|c|}{$\begin{array}{r}20 \\
0\end{array}$} & \multicolumn{2}{|c|}{$\begin{array}{r}20 \\
0\end{array}$} & \multicolumn{2}{|c|}{$\begin{array}{r}20 \\
0\end{array}$} & \multicolumn{2}{|c|}{$\begin{array}{l}20 \\
10\end{array}$} \\
\hline Switch position & \multicolumn{2}{|c|}{$\mathrm{L}$} & \multicolumn{2}{|c|}{$\mathrm{L}$} & \multicolumn{2}{|c|}{$\mathrm{X}$} & \multicolumn{2}{|c|}{$\mathrm{L}$} \\
\hline $\mathrm{m} / \mathrm{e}$ & p.h. & p.c. & p.h. & p.c. & p.h. & p.c. & p.h. & p.c. \\
\hline 15 & - & & - & & 7.3 & 0.4 & - & \\
\hline 26 & - & & - & & 2.7 & 0.2 & - & \\
\hline 27 & - & & 4.1 & 1.1 & 154.8 & 8.7 & - & \\
\hline 28 & 16.8 & 13.7 & 69.0 & 17.9 & 523.0 & 29.5 & 36.7 & 14.9 \\
\hline 29 & 7.2 & 5.9 & 48.9 & 12.7 & 528.0 & 29.8 & 17.2 & 7.0 \\
\hline 40 & - & & 0.2 & 0.0 & 2.9 & 0.2 & - & \\
\hline 41 & 0.8 & 0.7 & 18.2 & 4.7 & 153.0 & 8.6 & 1.8 & 0.7 \\
\hline 42 & 17.0 & 13.9 & 46.2 & 12.0 & 212.1 & 12.0 & 33.2 & 13.5 \\
\hline 43 & 122.4 & 100 & 385.0 & 100 & 1770.0 & 100 & 246.0 & 100 \\
\hline 55 & 一 & & - & & 1.3 & 0.1 & - & \\
\hline 56 & 0.9 & 0.7 & 2.5 & 0.6 & 10.0 & 0.6 & 1.5 & 0.6 \\
\hline 57 & 1.8 & 1.5 & 8.8 & 2.3 & 33.3 & 1.9 & 4.0 & 1.6 \\
\hline 58 & 20.8 & 17.0 & 47.0 & 12.2 & 184.2 & 10.4 & 40.0 & 16.3 \\
\hline $\begin{array}{l}\text { sample } \\
\text { pressure }(\mu)\end{array}$ & \multicolumn{2}{|c|}{42.7} & \multicolumn{2}{|c|}{42.0} & \multicolumn{2}{|c|}{47.6} & \multicolumn{2}{|c|}{41.6} \\
\hline
\end{tabular}

I.R. : Inner repeller

O.R. : Outer repeller

p.h. : Peak height

p.c. : Pattern coefficient

Switch position : same meaning of that in Table 1 


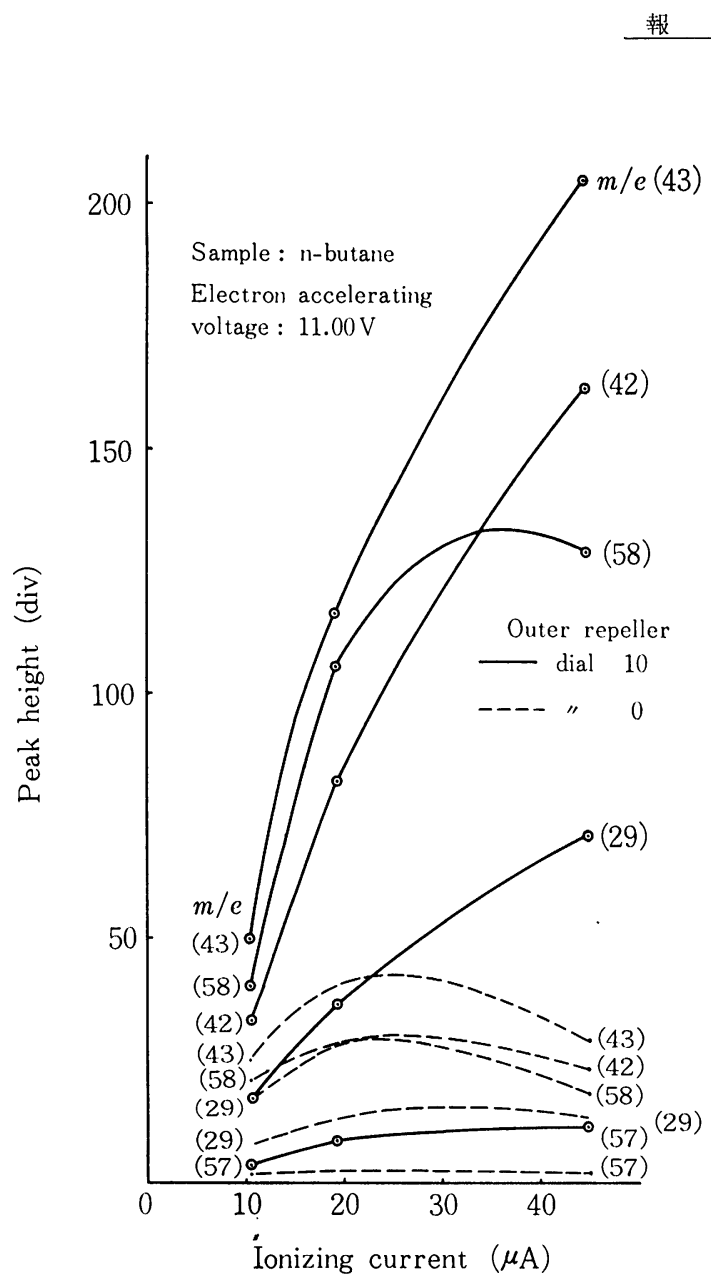

Fig. 4. Effect of ionizing current on the peak heights of $n$-butane.

ピーク留さを间くするには，i）イオン化電流を大に する。ii）試料圷を上げる。iii) 電子加速電国を上げる。 などが菶えられる。しかし ii) は二次イオンの生成や 比例性の低下などが将えられるので i) について nブダンを試料として検対した。結果を Fig. 4 に示す。

头線は Outer Repeller のダイヤルを10目盛にした 埸合で，イオン化電流とピーク间さの間にはほぼ比例 性が涩められる。しかし $m / e 58$ のピークは $45 \mu \mathrm{A} に$ したときに增加が少なく，イオン化電流をあまり大に するのは好ましくないと若えられる。

破線は Outer Repeller ダイヤルを0にした㺃合で，

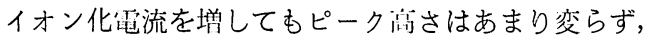
感度も低く，てのような杀件は不適当であった。通常

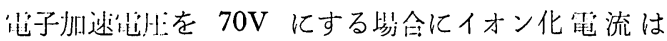
$10.5 \mu \mathrm{A}$ (10 の所はメータの目盛線が太心ので 10.5 にしている）で測定を行なっている。低電版の場合も 同じ条件で测定する方が此較する場命に便利であり，
質些分 析

後述するように電子加速電生を適当に選べば，ピーク 高さもそれ程低くないので, 以後イオン化電流は 10.5 $\mu \mathrm{A}$ とすることにした。また低電圧では, フィラメン ト電流が増すので，イオン化電流を大にするとフィラ メントが切れ易くなることも考えられる。

\section{4. 質量スペクトルの再現性}

䉓子加速電压の低いところでは，電生を変えると急 激にイオン旦が变化するので, パタン係数や感度の再 現性が恶いといわれている6)。n-ブタンを試料として 検刘した絬果を Table 3，4，に示す。

Table 3 はリペラー電王を変えて測定した場合で, 5８回の測定の平均值を示し，Table 4 には3.2., 3.3. でも述べた最適条件で测定した個々のデータを示した。 なお電子加速電王は正確に設定できる箱囲で最高の 11,000V を選んだ。

Table 4 でわかるように電子扣速電圧を正確に設定 すれば，パタン係数，感度ともに良い再現性が得られ， したがって再現性が恶いのは電子加速電王に原因があ ると考えられる。

以上の結果加，電子加速電王を变えると，乙の装 䈯でも分子構造に関連したスペクトルが得られるとい えよう。

\section{4. 低エネルギー電子衝撃について}

\section{1. 電子加速電圧とスペクトル}

電子扣迷㧛压を変えてスペクトルを测定し，いわゆ るイオン化効摔曲線を描くと，イオンの種類により異 なった曲線が得られる77。との曲線の形からどのよう なイオンができているかをある程度推定でき，また分 子のイオン化電归より 2〜 $4 \mathrm{~V}$ 位高い電圧で测定した スペクトルと，通常の $70 \mathrm{~V}$ で測定したスペクトルを 比較すると構造推定が容易になるととを前報らで報告 した。

電止を低くした埸合にどの位の電迌が適当かは化合 物によっても暴なると考えられるが， $70 \mathrm{~V}$ の埸合と は染ってフラグメントの少ないスペクトルが得られて， しかもピークがなるべく高い方が良い，とすると前述 のようにイオン化電压より 2〜4V 高い電玨が良いよ うである。ただしピークの質量数を間進える伦険性が あること，および低電王でのスペクトルの変化が構造 推定に役立つので，イオン化電压 $+10 \mathrm{~V}$ 程度の籁畴 でさらに1〜2点測定する力がより確夷である。

\section{2. 電子加速電圧を低くした場合のスペクトル}

通常低エネルギー電子衝整法というと，親イオンの みが生:成するような条件で测定することであるが，我 々の場命はむしろ少しフラグメントができるような条 件で測定を行なう。この埸合に生成するイオンは主と して，比較的切机易い結合が 1 简所犬゙け切れてできる 
Table 3 Pattern coefficients of n-butane at various repeller voltages

\begin{tabular}{|c|c|c|c|c|c|c|}
\hline $\begin{array}{l}\text { Repeller } \\
\text { voltage } \\
\text { dial }\end{array}\left\{\begin{array}{l}\text { I.R } \\
\text { O.R. }\end{array}\right.$ & \multicolumn{2}{|r|}{$\begin{array}{l}10 \\
10\end{array}$} & \multicolumn{2}{|r|}{$\begin{array}{r}20 \\
0\end{array}$} & \multicolumn{2}{|r|}{$\begin{array}{l}20 \\
10\end{array}$} \\
\hline $\mathrm{m} / \mathrm{e}$ & $\begin{array}{l}\text { Pattern } \\
\text { coeff. }\end{array}$ & $\begin{array}{l}\text { Std. } \\
\text { deviation }\end{array}$ & $\begin{array}{l}\text { Pattern } \\
\text { coeff. }\end{array}$ & $\begin{array}{l}\text { Std. } \\
\text { deviation }\end{array}$ & $\begin{array}{l}\text { Pattern } \\
\text { coeff. }\end{array}$ & $\begin{array}{l}\text { Std. } \\
\text { deviation }\end{array}$ \\
\hline 28 & 12.9 & 0.8 & 14.0 & 1.0 & 14.7 & 0.2 \\
\hline 29 & 4.7 & 0.5 & 5.4 & 0.4 & 6.3 & 0.3 \\
\hline 42 & 15.1 & 0.9 & 13.8 & 0.7 & 13.7 & 0.2 \\
\hline 43 & 100 & & 100 & & 100 & \\
\hline 58 & 18.7 & 1.0 & 16.5 & 0.5 & 16.6 & 0.2 \\
\hline $\begin{array}{c}\text { Sensitivity } \\
(\text { div. } / \mu)\end{array}$ & 3.3 & 0.2 & 3.2 & 0.3 & 7.1 & 0.3 \\
\hline
\end{tabular}

Electron accelerating voltage $: 11.000 \mathrm{~V}$

Ionizing current : $10.5 \mu \mathrm{A}$

Table 4 Pattern coefficients of n-butane, Reproducibility at optimum condition

\begin{tabular}{c|ccccccc|c}
\hline \hline $\mathrm{m} / \mathrm{e}$ & 1 & 2 & 3 & 4 & 5 & 6 & average \\
\hline 28 & 14.5 & 14.6 & 14.9 & 14.9 & 14.6 & 14.8 & 14.7 \\
29 & 5.8 & 6.3 & 6.3 & 6.7 & 6.0 & 6.4 & 6.3 \\
42 & 13.7 & 13.7 & 13.8 & 13.9 & 13.2 & 13.6 & 13.7 \\
43 & 100 & 100 & 100 & 100 & 100 & 100 & 100 & 3.1 \\
44 & 2.8 & 3.1 & 3.3 & 3.1 & 2.9 & 3.2 & 16.7 & 16.6 \\
58 & 16.8 & 16.5 & 16.8 & 16.7 & 16.1 & 16.7 & 7.1 \\
\hline $\begin{array}{c}\text { Sensitivity } \\
\text { (div./ } \mu \text { ) }\end{array}$ & 6.9 & 7.7 & 6.9 & 7.4 & 7.0 & 6.8 & & 7.8 \\
\hline
\end{tabular}

Electron accelerating voltage $: 11.000 \mathrm{~V}$

Ionizing current: $10.5 \mu \mathrm{A}$

Inner repeller dial: 20

Outer repeller dial: 10

Sample pressure: about $40 \mu$

フラグメントイオン（環状化合物の場合は 2 籄所切れ るととがある。), リアレンジメントイオン，および親 イオンである51。

4 種の分子量 74 の化合物のパタン係数を Table 5 に，イオン化効率曲線を Fig. 3，5〜7 に示した。

結合が 1 筐所切れてできるイオン，いわゆる simple cleavage によるイオンは，たとえば Table 5 の m/e 59, 45 43, 31 などである。乙れらのイオンには，低 電圧にしたときに相対的に量が増すむのと娍るあのが あり，前者は比較的小さい側鎖が切れ易い屯ので， $\mathrm{C}_{2} \mathrm{H}_{5} \cdot\left(\mathrm{CH}_{3}\right) \cdot \mathrm{CHOH}$ や $\mathrm{CH}_{3}-\mathrm{CH}_{2}-\mathrm{O}--\mathrm{CH}_{2}-$ $\mathrm{CH}_{3}$ の m/e 59 であり, 後者は比較的小さいイオン か，他に安定なリアレンジメントイオンができるよう な場合で， $\mathrm{n}$ - および $\mathrm{i}$ - ブタノールの $m / e 43$ や 31 である。概して大きなパタン係数を示し，たとえげ 2 級ブタノールの $m / e 45$ は $\left(\mathrm{CH}_{3}-\mathrm{C} \mathrm{HOH}\right)$ 極めて生 成し易く安定なイオンで, $70 \mathrm{~V}$ でも低電圧でも最大ピ ークとなる。

リアレンジメントイオンは，低電圧にしたとき顕著
な変化を示す。一つは $\mathrm{n}$ - ブタノールの $m / e$ 56, iブタノールの $m / e 33$ あるいは酢酸エステルの $m / e$ 615) などのように親イオンから直接リアレンジしてで きるイオンであって，低電苼にするとパタン係数が大 きくなることが多い。特にリアレンジによって低いエ ネルギーでイオンができる場合には最大ピークになる。 一方フラグメントイオンからリアレンジしてできる イオンは，結合が 2 ケ所（C-H 間の結合は考虑しな い）以上切れる必要があるため低電王にすると小さく なる。Table 5 では二級ブタノールおよびジエチルエ 一テルの $m / e 31$ である。エーテルの場合パタン係数

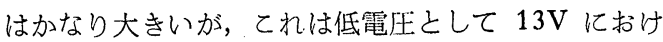
る值を示したた姁で，前報らにも述べたようにも少し 低い電压にすると $m / e 31$ のピークはなくなり $m / e$ 59からのリアレンジであることを示す。(Fig. 3)

親イオンは一般にパタン係数が增すが, Table 5 で あわかるように 70Vであ小さい場合にはほとんど低 電左であ小さいままである。従ってとのような化合物 では，親イオンによって分子量をきめるのは難かしい。 
Table 5 Comparison of mass spectra of 4 compounds at different electron accelerating voltages

\begin{tabular}{|c|c|c|c|c|c|c|c|c|}
\hline \multirow[b]{2}{*}{$\mathrm{m} / \mathrm{e}$} & \multicolumn{2}{|c|}{$\begin{array}{l}\mathrm{CH}_{3}-\mathrm{CH}_{2}-\mathrm{CH}_{2}- \\
\mathrm{CH}_{2}-\mathrm{OH}\end{array}$} & \multicolumn{2}{|c|}{ 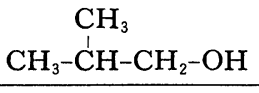 } & \multicolumn{2}{|c|}{$\begin{array}{c}\mathrm{CH}_{3} \\
\mathrm{CH}_{3}-\mathrm{CH}_{2}-\mathrm{CH}-\mathrm{OH} \\
\end{array}$} & \multicolumn{2}{|c|}{$\mathrm{CH}_{3}-\mathrm{CH}_{2}-\mathrm{O}-\mathrm{CH}_{2}-\mathrm{CH}_{3}$} \\
\hline & $\mathrm{H}$ & $\mathrm{L}$ & $\mathrm{H}$ & $\mathrm{L}$ & $\mathrm{H}$ & $\mathrm{L}$ & $\mathrm{H}$ & $\mathrm{L}$ \\
\hline 74 & 0.7 & 0.9 & 8.8 & 16.2 & 0.3 & 0.8 & 23.8 & 75.3 \\
\hline 59 & 0.3 & & 6.4 & 4.5 & 21.4 & 36.4 & 43.9 & 100 \\
\hline 57 & 6.8 & 4.7 & 5.0 & 1.3 & 3.6 & 1.1 & & \\
\hline 56 & 95.2 & 100 & 3.9 & 4.3 & 1.3 & 1.3 & & \\
\hline 55 & 13.8 & 1.8 & 5.6 & & 2.7 & & & \\
\hline 45 & 7.3 & 0.5 & 6.2 & 2.3 & 100 & 100 & 34.9 & 26.7 \\
\hline 43 & 63.7 & 11.0 & 100 & 40.9 & 13.7 & 1.1 & 9.2 & 1.0 \\
\hline 42 & 33.5 & 10.3 & 58.4 & 49.8 & 2.4 & & 1.9 & \\
\hline 41 & 69.7 & 7.6 & 63.9 & 1.4 & 12.1 & 1.4 & 3.3 & 5.2 \\
\hline 33 & 7.8 & 5.3 & 48.5 & 100 & 0.1 & & & \\
\hline 31 & 100 & 17.2 & 68.5 & 10.7 & 21.2 & 3.7 & 100 & 36.6 \\
\hline 29 & 32.8 & 0.4 & 25.2 & 0.4 & 16.4 & 0.4 & 61.5 & 3.6 \\
\hline 28 & 22.4 & 0.6 & 15.4 & 0.4 & 10.8 & & 8.0 & 0.4 \\
\hline 27 & 57.6 & 0.3 & 46.9 & & 19.3 & & 33.7 & \\
\hline
\end{tabular}

$\mathrm{H}:$ Electron accelerating voltage is $70 \mathrm{~V}$

$\mathrm{L}$ : Electron accelerating voltage is $13 \mathrm{~V}$

前述のように低䒜压では親イオンから小さい伶銧のと 机たイオンが大きくなるととが多いので，乙の知見を 利用すると良いと思わ机る。

\section{3. 分子構造の推定}

饮圤スペクトルから分子構造を推定する力法を,

Table 5 について検幜してみる。

まず 4 つの化合物に其通していえることは， $m / e 31$ ， 45,59 などのパタン係数が大きいととから念酸素化合 物で，凌素は 1 ケ入っているとと，小さいピークだが， 饮量数が最大で偶数であることから $m / e 74$ が親イオ ンで，すな拈化学式は $\mathrm{C}_{4} \mathrm{H}_{10} \mathrm{O}$ であるというとと である。

4.3.1. n一ブタノールについて

m/e 31 が大きくしかむ33まであるのはエーテルな どではなくてー $\mathrm{CH}_{2} \mathrm{OH}$ があるととを示す。 $m / e 57$ 〜 55, 43 41，29〜27 が大きいし分子量が 74 である からブチル尐があることがわかる。

$m / e 56$ はい犼ゆる $\left(\mathrm{P}-\mathrm{H}_{2} \mathrm{O}\right)$ イオンでかつ $\mathrm{C}_{4} \mathrm{H}_{8}$ の オレフィンタイプイオンであって低雷生では特に生成 し少いイオンである。一般に直鎖の埸合に $m / e 42$ や 56 のイオンができ努く, また $m / e 43$ の $\mathrm{C}_{3}$ グルー プが低帒压で小さいととから，てれが n-ブタノール であると推定さ机る。

4.3 .2 i- ブタノールについて

4.3 .1 と同じく $m / e 31$ と 33 から $-\mathrm{CH}_{2} \mathrm{OH}$ が あるといえる。33が特に低想压で諟大ピークになるて とは - $\mathrm{CH}_{2} \mathrm{OH}$ に $\mathrm{H}$ を实光多い形になっていると
考えられ，しかも $m / e$ 43〜41 が大きいとと（70Vで 100 ，低電圧であ大）加ら，と机易い $\mathrm{C}_{3} \mathrm{H}_{7}$-をむって いると推定される。すな和ち i- ブタノールである。 （59）はとれ易いメチル基があるととを示し，この推定 を文持する。

なお m/e 33 はリアレンジメントイオン $\left(\mathrm{CH}_{3}{ }^{+} \mathrm{H}_{2}\right)$

で，安定な Oxonium イオンになっている。

4.3.3. 第 2 級ブタノール

m/e 45 が大きい莂合に, $\mathrm{CH}_{3}-\mathrm{CHOH}$ や $\mathrm{CH}_{3}-$ $\mathrm{CH}_{2}-\mathrm{O}-\mathrm{R}$ などが考元ら机るが， $m / e 31$ が小さい ことが，エーデルではないととを示し， m/e 59 が低 電理で少し大きくなることは $\mathrm{CH}_{3}-\mathrm{CH}_{2}-\stackrel{\mathrm{C}}{\mathrm{C}} \mathrm{H}-\mathrm{OH}$ の芬合と一致し，また $m / e 43$ のグループが低電玨で 非常に小さいことは $\mathrm{C}_{3} \mathrm{H}_{7}$ ができにくいことを示して おり，乙机が 2 級ブタノールであるととを確实にする。 なお $m / e 44$ は曲線の形 (Fig. 7) からリアレンジ メントイオンと考えられ，確実ではないが次のような 構造が推定される。

$$
\begin{aligned}
& \mathrm{CH}_{3}-\stackrel{\mathrm{C}_{2}}{\mathrm{C}_{2}}: \stackrel{\mathrm{CH}_{3}}{\mathrm{C}} \mathrm{H}-\stackrel{+}{\mathrm{O}} \mathrm{H} \longrightarrow \\
& \mathrm{CH}_{3}-\mathrm{CH}_{3}+\stackrel{\mathrm{CH}_{2}}{\mathrm{C}} \mathrm{H}-\stackrel{\mathrm{O}}{\mathrm{H}}
\end{aligned}
$$

4.3.4. ジェチルエーテルについて エーテルの $m / e 31$ は $\mathrm{CH}_{2}=\stackrel{\mathrm{O}}{\mathrm{O}}$ でリアレンジメ ントイオンであるが，70V では大きなパタン係数を 示すととが多い。低電王にすると Fig. 3 でわかるよ 


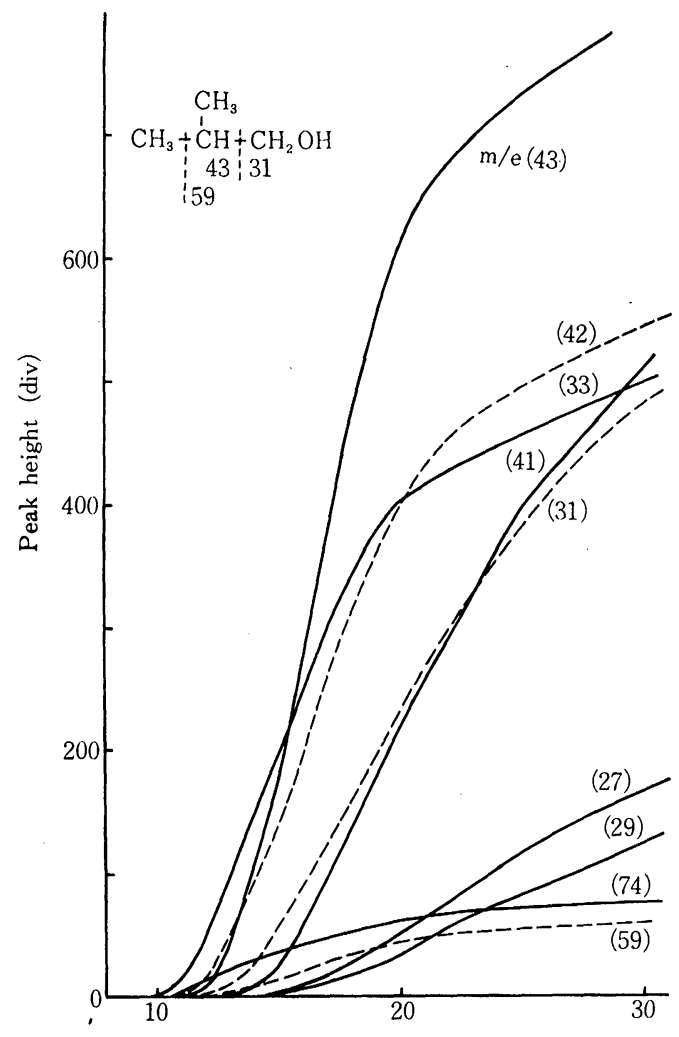

Electron accelerating voltage (V)

Fig. 6. Ionization efficiency curves of iso-butyl alcohol.

うに 16 17V で $m / 59$ 之量的関係が逆転し，590イ オンから31のイオンができるととを推定できる。

$$
\mathrm{CH}_{3}-\mathrm{CH}_{2}-\stackrel{+}{\mathrm{O}}=\mathrm{CH}_{2} \longrightarrow
$$

(59)

$$
\mathrm{CH}_{2}=\mathrm{CH}_{2}+\mathrm{H}-\stackrel{+}{\mathrm{O}}=\mathrm{CH}_{2}
$$

また〉 $\mathrm{CH}-\mathrm{OH}-\mathrm{C}$ - $\mathrm{OH}$ を含む化合物む $m / e$ 31 を生ずるがピークは小さく, $\mathrm{CH}_{3}-\mathrm{O}-\mathrm{CH}_{2}-$ $\mathrm{CH}_{2}$ 一では $m / e 58$ が大くてやはり 31 は小い。乙 れらのことからあ，乙の化合物には $\mathrm{CH}_{3}-\mathrm{CH}_{2}-\mathrm{O}$ 一 $\mathrm{CH}_{2}$ 一があり, 従ってジェチルエーテルであると決 定される。

質量スペクトルから構造を推定する場合には，ある 質量数がどのような構造のフラグメントに刘応するか を知る必裂がある。ことに述べたように m/e 59 と31 あるいは58といったように関連するピークの大小関係 を較べることによってある程度の知識が得られ，さら に電子のエネルギーによる变化を見るととにより，よ
り確かな測定が可能になると考えられる。

質量数之構造との関係は, 多くの化合物のスペクト ルを整理することによって得られ，目下検討中なので， 剠の機会に㹁告する予定である。

\section{5. 結論}

CEC 21-103 C 型翼量分析計の回路の一部を改造 し，低エネルギー電子衝撃ができるようにした。测定 条件が適当であれば，電子加速電压が低いととろでも， 再現性のある, 分子構造と密接な関係のある澌量スペ クトルが得られることがわかった。

低電压での斦量スペクトルは simple cleavage によ るイオンとリアレンジメントイオンが主であって, 通 常の $70 \mathrm{~V}$ でのスペクトルと比較するととにより, 構 造推定に役立つ多くの知見が得られる。

複雑な構造の化合物では，乙の方法でも必ずしも構 造推定ができるとは云元ないが，多くの化合物につい てこのような関係を整理すれば，分子構造の推定に大 いに役立つと考えられる。 


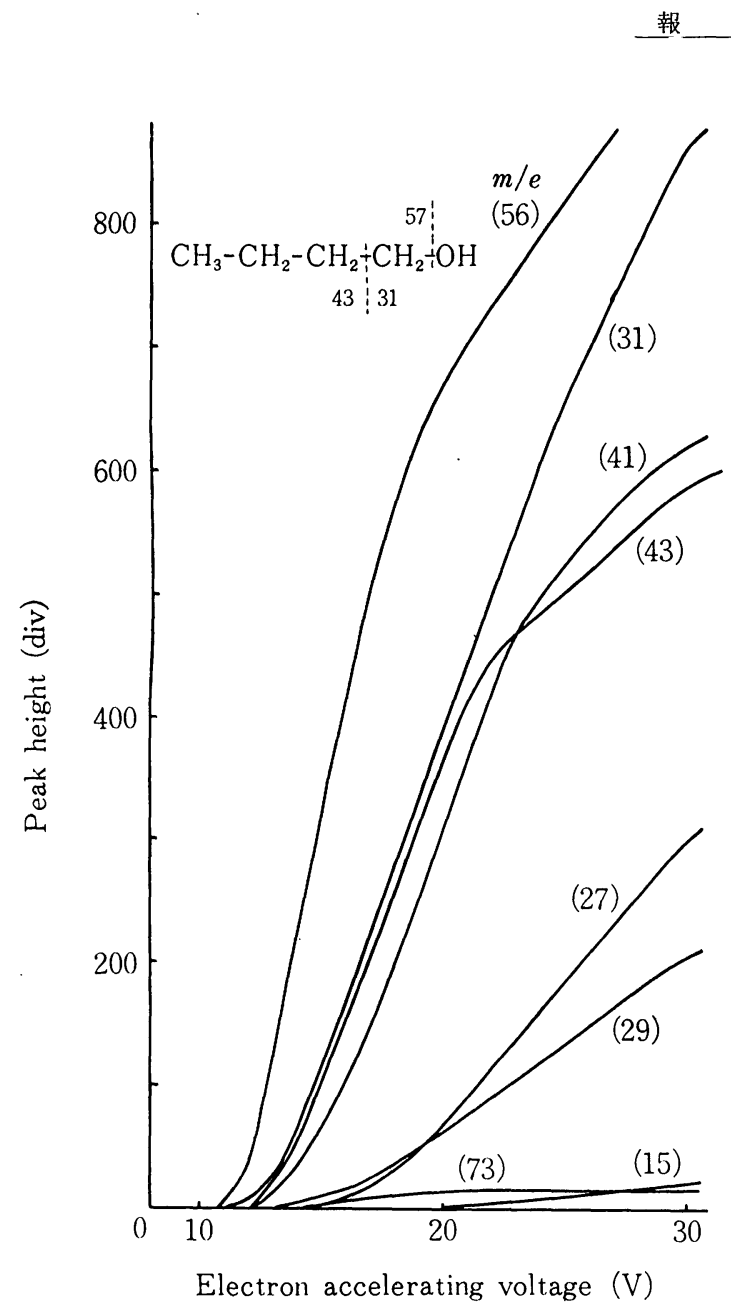

Fig.5. Ionization efficiency curves of n-butyl aicohol.

$$
\text { 文献 }
$$

1) 酉野䇺：分析化学 10,591 (1961).

2) F.W. McLafferty: "Mass Spectral Correlations”, (1963) (American Chemical Society, Washington, D.C.)

3) API data (American Petroleum Institute Research Project No. 44 Mass Spectral Data).

4) “Index of Mass Spectral Data”, (1963) (ASTM

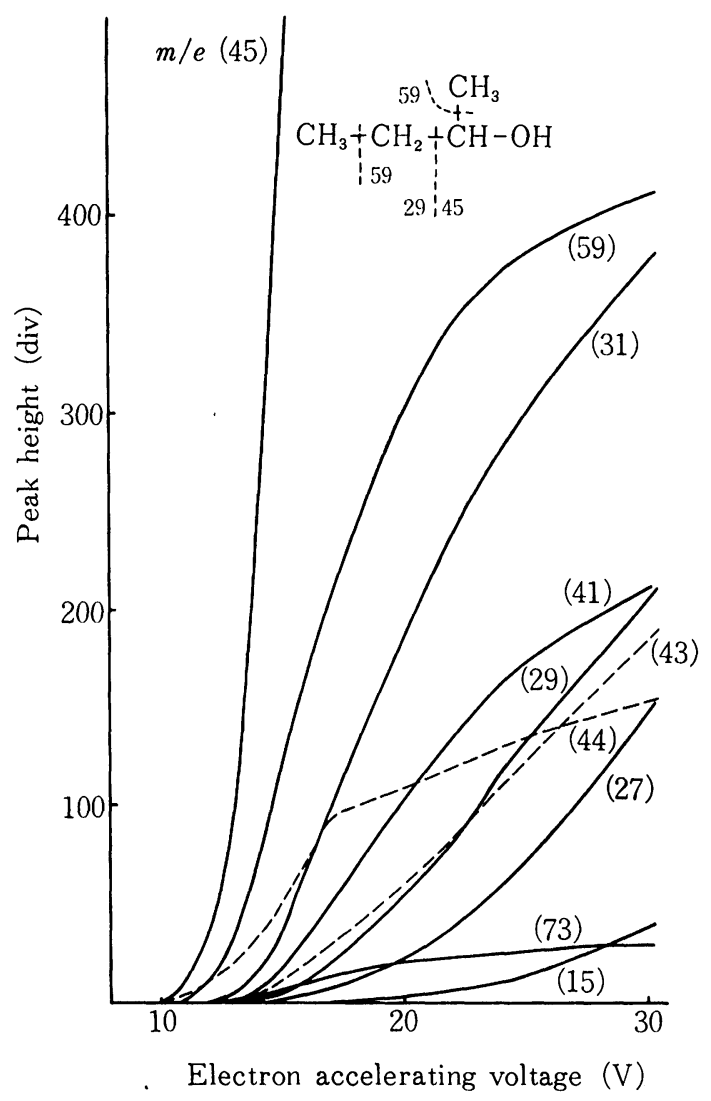

Fig. 7. Ionization efficiency curves of sec-butyl alcohol.

Committee E14 on Mass Spectrometry, Philadelphia).

5）土屋正彦，松比良伸也，鎌田 仁：分析化学 14, 465 (1965).

6) H.E. Lumpkin: Anal. Chem., 30, 321 (1958).

7) I. Omura: Bull. Chem. Soc. Japan, 34, 1227 (1961). D.P. Stevenson, J.A. Hipple: J. Am. Chem. Soc. 64, 1588 (1942). など 